\title{
Evaluation of Candidate-teacher Training Process by Candidate-teachers of Primary School ${ }^{i}$
}

\author{
Murat Çalışoğlu*, Seda Nur Tanışır \\ Faculty of Education, Ağr İbrahim Çeçen University, Ağrı, Turkey
}

Copyright $\bigcirc 2018$ by authors, all rights reserved. Authors agree that this article remains permanently open access under the terms of the Creative Commons Attribution License 4.0 International License

\begin{abstract}
With the changes done in the teacher training process in Turkey, the teachers who are going to begin active duty are asked to take a candidate teacher training under the supervision of an advisor teacher before they start their duty in the city they have been appointed, and these changes have been introduced in 2015-2016 academic years. In this study, it was aimed to evaluate Candidate Teacher Training being applied since 2015-2016 in our country. The study was conducted with 20 classroom teachers who were appointed as teachers in February in 2015-2016 academic years and took their candidate teacher training in Ağrı. Case study which is one of the qualitative research models was used in the study. Descriptive survey model was used in the study. The data of the study was collected with interviews, 6 open-ended questions prepared by the researchers were asked to the candidate teachers and the obtained answers were analyzed through content analysis. At the end of the study, the candidate teachers expressed their positive opinions on related to their experiences, their knowledge about the school work and operations in the Candidate Teacher Training Process by using the experience of the supervisor and the seminar teachers. However, it was determined that the candidate teachers confront many problems particularly in implementation. The candidate teachers expressed that a much more effective training can be applied by removing the existing problems with the recommendations they made about the process.
\end{abstract}

Keywords Candidate Teacher, Classroom Teacher, Education

\section{Introduction}

Education can be defined as all of the activities to develop new abilities, behaviors, and information for a set of goals to develop the individual's mind, body, emotional and social abilities in the most appropriate way or in a desired direction [1]. In addition to this, it can be defined as "the process of deliberately changing the behavior of the individual through his own experience" [9]. Or finding the laws and principles necessary for the planned change and development of the individual's behavior according to certain purposes and developing techniques for this purpose [2].

Teaching, on the other hand, can be defined as the transfer of information to the students by the teachers in a planned and regular manner in an educational institution. According to Çalık [8], "Teaching is the part of the educational process that takes place in a planned, programmed and purposeful way of teaching-learning relationship. It is the act of organizing, providing tools and guiding activities that will facilitate learning. "

According to Sünbül [14], "Teachers are the key person responsible for teaching." Teacher is the most basic element of the education system, because the quality of education depends largely on the quality of the teacher [17]. It is possible for teachers to grow up as an expert with professional qualifications by getting a great deal of pre-service training. Today, pre-service education, also called pedagogical formation, has a program that covers field knowledge, vocational knowledge and general culture courses. However, the training of good teachers depends on a sufficient level of education before the care and service to be shown in the selection of candidates [16].

Various practices related to teacher training have been made from past to present. The first serious step taken on this path was the first Teacher's School opened in 1848. Until the 19th century in the Ottoman period, the teachers were educated in madrasah without any special training [4]. In the reign of Mehmet the Conqueror, a different program than the general ones was envisaged in the Eyüp and Hagia Sophia Medreselas for being a lecturer in the infant's school; Adâb-1 Mubahase and Usuli Tedris courses were requested to be taught. The fact that this course which was going to gain teaching formation was considered compulsory was an important novelty in this era. The Islamic law lessons were not considered to be useful for elementary school teachers even though they were considered as suitable for general madrasa students [18]. 
During the reign of Sultan Abdülmecid, a school was opened for the first time under the name of Darülmuallim, a school of teachers on March 16, 1848. "Darülmuallimin was opened in Turkey to teach pedagogy, effective teaching methods, and train teachers in this direction." [1]

According to Akyüz [1], one of the positive educational activities of the autocracy period is the instruction to make the teacher become a profession. According to Akyüz [1], "The following conditions have been introduced for the introduction of the teaching profession: 1. Good morals and behavior 2. Not to deal with any other duty or duty other than the teaching profession 3. To adhere to the loyalty and expertise of the course" according to the basic provisions of the document entitled Instructions on the Establishment of Occupational Training (Muallimlikte Meslek-i İhtisas Tesisine Dair Talimat). Starting from the 1875 s, primary school teacher education in the province started with the opening of Dârulmuallimî in Bosnia, Crete and Konya for this purpose $[16,18]$.

During the $2^{\text {nd }}$ Constitutional Monarchy, the primary school branch of the Istanbul Teacher Training School (Dârülmuallimîn) became an independent school of teachers [12]. Mustafa Sâtı Bey, the famous educator of the period, was brought to the directorate of the branch. After the beginning of Mustafa Sâtı Bey, significant changes took place in primary school branch of the teacher training school: Firstly, he finished with the relations of many students who did not fit into the teaching profession with the school. It was ensured that teachers developed relationships with students by ensuring they stayed at school at least once a week; which had had no other precedent. For the first time in Teacher Training School, application school was opened for the first time. For the purpose of increasing the knowledge of the students of Teacher Training School, congresses of Teacher Training School were organized and various issues related to education were discussed with these congresses. After Mustafa Sâtı Bey came to the school, the school curriculum included teaching profession formation lessons, gym lessons and music and painting lessons in real sense. Considering the training period was inadequate, he increased it to three years from two years [4]. However, Istanbul Teacher Training School, an important school during Mustafa Satı Bey's time, trained teachers as "away from national issues, fairly empty and with book information" [1]. Despite the fact that in the Constitutional period, training qualified and numerous male and female teachers were taken as the basis, with the notice published by Maarif Nazırı Emrullah Efendi in the newspapers in 1910, those who only were literate would even be given teaching license and they would be appointed as teachers [1].

In the first years of the Republic, more attention was paid to the theoretical courses, and vocational courses and practical studies were not taken into consideration in detail [1]. After a large number of changes in teacher resources, reserve officer teachers, substitute teachers, peace volunteers, those who graduated from various faculties and took pedagogical formation courses, teachers who were educated through letters and accelerated programs, teachers who done their military service as teacher and all faculty and college graduates were assigned as teachers [1].

In 1940, Village Institutes were established by encating the Law on Village Institutes [10]. "The British historian TonyBe described Village Institutes as bridges built on the abyss" [5]. It was aimed to educate qualified teachers with little budget through village institutes [3]. "In this application, primary school graduates were taken to the schools and trained for 5 years, and those who graduated were allowed to teach again in the villages. The most important difference of this institution from other institutions is that they provide teacher education by giving an education based on practice, and also the teachers' guide the villagers and illuminate the villagers about agricultural technical knowledge and skills" [19].

In 1954, with the decision taken in the $5^{\text {th }}$ Education Council, all primary education teacher training institutions (village institutes) were combined under the name of primary education schools $[3,11,15]$.

Educational institutes established in 1974 were opened with the purpose of meeting the new needs and to close the teacher gap as part of some primary education schools. This institute did not meet the needs of the secondary school teachers of the country in the time. In the education institutes, field knowledge, teaching profession courses and general culture courses were taught. It was aimed to put knowledge into practice with the education in education institutes which was increased from two years to three years [19].

The education period of the education colleges established in 1982 was determined as 4 years in 1989-1990 academic year. In the 1992-1993 school year, high education institutes were transferred to the education faculties [3].

Today, education in elementary education in education faculties lasts 4 years. Secondary school teachers' education lasts for 5 years and students who graduate from other faculties become teachers in the secondary school after 1 year of formation education after undergraduate education. Candidate teachers who are appointed as teachers undergo at least one year or maximum two years of candidacy and internship. Those who succeed in this period are appointed as regular teachers [3].

A new application, "Candidate Teacher Training Process", was launched with the February 2016 appointment. [13]. In this process, the candidate teachers received an internship for 3.5 months alongside the supervisor teachers and received seminars on topics determined by the Ministry of National Education (MoNE) during the summer vacation. The condition of having worked in MoNE was sought for at least ten years while the supervisor teacher was determined. No problem was 
encountered in the classroom teacher branch due to the fact that there were enough experienced teachers in choosing the supervisor teacher. But flexibility has been provided in the requirement of being worked ten years in MoNE, so that the branch teacher circulation was excessive and sufficient number of branch teachers could not be found nor supervisor teachers were identified. The roles of the supervisors were identified as in the $2016 \mathrm{MoNe}$ program. With the start of the academic year 2016-2017, candidate teachers have begun to working the institution they were appointed. "The content of this education constitutes in-class, in-school, out-of-school activities and in-service training seminars." (SETA, 2017). No studies were found in the field of "Candidate Teacher Training Process" during the literature review. For this reason, it is expected that our work will contribute to the field.

\subsection{Purpose}

The purpose of this study is to determine the views of the candidate classroom teachers about the Candidate Teacher Training Process. In response to this main objective, answers to the following questions were sought:

- What are your thoughts about the education you have received during the candidate teacher training process?

- What are your opinions about your advisor teacher's guidance to you throughout the process?

- What are your opinions about the determination of your advisor teacher and not being able to change throughout the process?

- What were the views of both the staff and the students at the school where you were during the candidacy training?

- What are the practices that you like and do not during the candidate teacher training process?

- What are your views and suggestions in terms of a better education given to candidate teachers within the program?

\section{Method}

In this section, the research model, study group, collection of data and analysis of data are included.

\subsection{Research Model}

The study was conducted in descriptive survey model. Descriptive survey is a group of studies aiming at collecting data to identify specific characteristics of a group [6]. In this type of research, a questionnaire is filled or interviews are done to learn attitudes, beliefs and thoughts of individuals. In the descriptive survey, the researcher can generally make generalizations about the universe by moving from the sample [7].

\subsection{Study Group}

In the study, all of the candidate classroom teachers assigned to the province of Ağrı with the assignment in February 2016 was reached. But, because some candidates did not agree to participate in the work and the reliability of data received from some candidates was low, the study has been completed with twenty candidate classroom teachers. The characteristics of the participants in the study group were indicated in Table 1 and Table 2.

Table 1. Frequency and percentage values of gender distribution of classroom teachers

\begin{tabular}{|c|c|c|}
\hline Gender & $\mathrm{f}$ & $\%$ \\
\hline Female & 14 & 70 \\
\hline Male & 6 & 30 \\
\hline Total & 20 & 100 \\
\hline
\end{tabular}

As shown in Table 1,70\% of class teachers participating in the study are female teachers and $30 \%$ are male teachers.

Table 2. Frequency and percentage values of classroom teachers in terms of university graduations

\begin{tabular}{|c|c|c|}
\hline The University They Graduated & $\mathrm{f}$ & $\%$ \\
\hline University of Ağrı İbrahim Çeçen & 8 & 40 \\
\hline University of Atatürk & 2 & 10 \\
\hline University of Recep Tayyip Erdoğan & 1 & 5 \\
\hline University of Artvin Çoruh & 1 & 5 \\
\hline University of Marmara & 1 & 5 \\
\hline University of Giresun & 1 & 5 \\
\hline University of Mehmet Akif Ersoy & 1 & 5 \\
\hline University of Erzincan & 1 & 5 \\
\hline University of Ankara & 1 & 5 \\
\hline University of Yüzüncü Y11 & 1 & 5 \\
\hline University of Sakarya & 1 & 5 \\
\hline University of Kafkas & 1 & 5 \\
\hline Total & 20 & 100 \\
\hline
\end{tabular}

As seen in Table $2,40 \%$ of the class teachers who participated in the study graduated from University of Ağr İbrahim Çeçen, $10 \%$ from University of Atatürk, $5 \%$ from University of Recep Tayyip Erdoğan, 5\% from Artvin Coruh University 5\% from Marmara University, 5\% from Giresun University, 5\% from Mehmet Akif Ersoy University, 5\% from Erzincan University, 5\% from Ankara University, 5\% from Marmara University, 5\% from Giresun University, 5\% from Erzincan University, 5\% 5\% from Sakarya University and 5\% from Kafkas University.

\subsection{Data Collection Tools}

During the data collection process of the study, an interview form has been prepared by taking the opinions of experts in the field and moving from the field in the direction of the purpose of study. In the prepared form, participants were asked questions about personal information and six open-ended questions. 


\subsection{Analysis of the Data}

Descriptive statistics were used in the analysis of the data. In descriptive statistics, the aim is to describe the data and explain the basic characteristics of the data [7]. In the presentation of the data, frequency and percentage distributions were utilized.

\section{Findings and Interpretation}

In this section, frequency and percentage distributions of the findings obtained in the research are tabulated, presented and interpreted.

Table 3-a. Frequency and percentage values of the positive answers of the candidate teachers to the question "What are your thoughts about the education you have received during the candidate teacher training process?"

\begin{tabular}{|c|c|c|}
\hline Positive Thoughts & $\mathrm{f}$ & $\%$ \\
\hline $\begin{array}{l}\text { Utilizing the experience of the advisor teacher and the } \\
\text { teachers who give seminars }\end{array}$ & 8 & 32 \\
\hline Experience and practice & 5 & 20 \\
\hline $\begin{array}{l}\text { Having information about school work and school } \\
\text { procedures }\end{array}$ & 2 & 8 \\
\hline Those who do not express a positive opinion & 2 & 8 \\
\hline Adaptation to the job & 1 & 4 \\
\hline Professional development & 1 & 4 \\
\hline Recognizing and adapting the environment & 1 & 4 \\
\hline $\begin{array}{l}\text { That the recommended films and books have an } \\
\text { educational aspect }\end{array}$ & 1 & 4 \\
\hline $\begin{array}{l}\text { Institutional visits within the scope of out-of-school } \\
\text { activities }\end{array}$ & 1 & 4 \\
\hline $\begin{array}{l}\text { Chances of seeing your own shortcomings about the } \\
\text { profession }\end{array}$ & 1 & 4 \\
\hline To be considered as a chance to rest after KPSS & 1 & 4 \\
\hline Low responsibilities & 1 & 4 \\
\hline Total & 25 & 100 \\
\hline
\end{tabular}

As can be seen in Table 3 -a, when the positive answers of the question "What are your thoughts about the education you have received during the candidate teacher training process" were examined, 12 different titles emerged. They are like $8 \%$ of them "information about school work and operations", $8 \%$ of them do not express "positive opinions", $4 \%$ of them say " 4\% "Professional development", $4 \%$ of them "Recognizing and adapting to the environment", $4 \%$ of them "Educational orientation of recommended films and books", $4 \%$ of them "Institutional visits to schools" $4 \%$ of them "the chance of seeing their own deficiencies and problems" $4 \%$ of them "being seen as a chance to rest after KPSS" and $4 \%$ of them "having less responsibility". CT-15 thinks that he has knowledge about candidate teacher training process and classroom management, relationships established with students, work and operations done in school administration. According to CT - 10, the recommended movies and books have educational features. CT - 4 believes that institutional visits in the training received are of great benefit. CT - 11 thinks that attending a course with an advisor teacher contributes to the candidate's teaching profession.

Table 3-b. Frequency and percentage values of the negative answers of the candidate teachers to the question "What are your thoughts about the education you have received during the candidate teacher training process?"

\begin{tabular}{|c|c|c|}
\hline Negative Thoughts & $\mathrm{f}$ & $\%$ \\
\hline Waste of time & 6 & 13,4 \\
\hline Candidate teacher does not attend the course alone & 6 & 13,4 \\
\hline $\begin{array}{l}\text { Prolonged extension of the process and no summer } \\
\text { vacation }\end{array}$ & 6 & 13,4 \\
\hline Exclusion from other teachers in the school & 6 & 13,4 \\
\hline Paper waste & 3 & 6,7 \\
\hline $\begin{array}{l}\text { The shortcomings resulting from the first application } \\
\text { of the process }\end{array}$ & 3 & 6,7 \\
\hline Candidate teachers are sent to vacant courses & 2 & 4,4 \\
\hline Out-of-school activities & 2 & 4,4 \\
\hline $\begin{array}{l}\text { No obligation to take internship in the appointed } \\
\text { school }\end{array}$ & 1 & 2,2 \\
\hline To be called as intern & 1 & 2,2 \\
\hline Being obliged to go and come back from the county & 1 & 2,2 \\
\hline $\begin{array}{l}\text { Not being paid the watch fee even being obliged to } \\
\text { keep watch }\end{array}$ & 1 & 2,2 \\
\hline The studies within the school activities are wasted & 1 & 2,2 \\
\hline No additional tuition fees & 1 & 2,2 \\
\hline That it doesn't contribute to the candidate teacher & 1 & 2,2 \\
\hline Lack of supervision & 1 & 2,2 \\
\hline $\begin{array}{l}\text { Not feeling himself/herself as a part of the school in } \\
\text { which s/he takes internship }\end{array}$ & 1 & 2,2 \\
\hline Moving away from the job & 1 & 2,2 \\
\hline $\begin{array}{l}\text { Candidate teachers are not allowed to attend courses } \\
\text { while paid teachers are }\end{array}$ & 1 & 2,2 \\
\hline Total & 45 & 100 \\
\hline
\end{tabular}

According to Table 3-b, the negative answers of the candidate teachers to the question "What are your thoughts about the education you have received during the candidate teacher training process?" are; $13,4 \%$ of them "waste of time, $13,4 \%$ of them "Candidate teachers do not attend the classroom alone", 13,4\% of them "Prolonged extension of the process and no summer vacation", $13,4 \%$ of them "Exclusion from other teachers in the school", $6.7 \%$ were "Paper waste", $6.7 \%$ of them "The shortcomings resulting from the first application of the process", $4.4 \%$ of them "Candidate teachers are sent to vacant courses", $4.4 \%$ of them "Out-of-school activities", 2,2\% of them "No obligation to take internship in the appointed school", $2,2 \%$ of them "To be called as intern", 2,2\% of them "Being obliged to go and come back from the county", $2,2 \%$ of them "Not being paid the watch fee even being obliged to keep watch", $2,2 \%$ of them "The studies within the school activities are wasted", $2,2 \%$ of them "No additional tuition fees", $2,2 \%$ of them "That it doesn't contribute to the candidate teacher", $2,2 \%$ of them "Lack of supervision", $2,2 \%$ of them "Not feeling himself/herself as a part of the 
school in which s/he takes internship", $2,2 \%$ of them "Moving away from the job" and 2,2\% of them "Candidate teachers are not allowed to attend courses while paid teachers are." According to CT-4, the process of recognizing and adapting the environment should be completed by passing the candidacy training at the appointed place, and there is no difference between the course of the school applications taken at the university and the candidate teacher training process. Also, being called as an intern teacher puts distance between the candidate teacher and other teachers and causes the candidate teacher to feel himself inadequate. According to CT - 10, being in the custody of the advisor while the course is being taught, being sent to the empty classrooms at the required hours to fill forms, not receiving watch fee despite keeping the watch, being deprived the candidate teachers of the additional tuition fees for all the seminars while others not, the right of summer vacation to be taken from the candidate teacher, the number of the forms to be filled is higher are the negative sides of the education received. According to CT - 9, that teachers who give counseling and seminars are not able to fully master the process and that they have to take candidate education in the city center while they live in the districts are the negative sides of the education received.

Table 4. The frequency and percentage values of the answers to the question were "What are your opinions about your advisor teacher's guidance to you throughout the process?"

\begin{tabular}{|c|c|c|}
\hline The Views related of the Guidance received & $\mathrm{f}$ & $\%$ \\
\hline I benefit from his/her experiences & 10 & 33,3 \\
\hline Classroom management & 5 & 16,6 \\
\hline He fulfilled his duties and responsibilities & 4 & 13,3 \\
\hline Not useful enough & 3 & 10 \\
\hline $\begin{array}{c}\text { He tried to help me as a result of his seminars and } \\
\text { researches he received }\end{array}$ & 2 & 6,6 \\
\hline $\begin{array}{c}\text { There was nothing positive } \\
\text { training on the process }\end{array}$ & 2 & 6,6 \\
\hline $\begin{array}{c}\text { Advisor teachers should be given more intensive } \\
\text { frustration }\end{array}$ & 1 & 3,4 \\
\hline $\begin{array}{c}\text { Leaving paperwork to candidate teachers } \\
\text { The works that are left to the candidate teachers create }\end{array}$ & 1 & 3,4 \\
\hline It was an inefficient process & 1 & 3,4 \\
\hline $\begin{array}{c}\text { Total } \\
\text { fark }\end{array}$ & 30 & 100 \\
\hline
\end{tabular}

As it can be seen in Table 4, according to the answers given by the candidate teachers who participated in the study to the question "What are your views on the guidance your counselor made to you during the process?" are; $33 \%$ of them "I benefit from his/her experiences", 16,6\% of them "Classroom management", $13,3 \%$ of them "He fulfilled his duties and responsibilities", $10 \%$ of them "Not useful enough", 6,6\% of them "He tried to help me as a result of his seminars and researches he received", $6,6 \%$ of them "There was nothing positive", 3,4\% of them "Advisor teachers should be given more intensive training on the process", 3,4\% of them "Leaving paperwork to candidate teachers", 3,4\% of them "The works that are left to the candidate teachers create frustration", and 3,4\% of them "It was an inefficient process." CT- 9 thinks that the advisor teacher knowledge about classroom management, teacher-student-parent relations, teaching methods and techniques by observing him/her. However, according to CT - 3, the advisor teacher was not helpful because of the lack of information about the process and the problems caused by the initial implementation of the process. CT-10 suggests that it is not appropriate for the advisor teacher to make the candidate teacher fill in the forms that should be filled in by him, and at the same time, that the teachers who are close to retirement are putting their job candidates to do because of both mental and physical fatigue makes the candidate teacher to feel like moving away from the profession.

Table 5. The frequency and percentage values of the answers to the question were "What are your views on the advisor teacher's determination and not being able to change him/her throughout the process?"

\begin{tabular}{|c|c|c|}
\hline $\begin{array}{c}\text { The Views related to the Determination of the } \\
\text { Advisor and not being able to Change him/her }\end{array}$ & $\mathrm{f}$ & $\%$ \\
\hline Advisor can be changed & 7 & 25 \\
\hline Advisor should not to change & 7 & 25 \\
\hline Advisor's competence should be considered & 3 & 10,73 \\
\hline $\begin{array}{c}\text { Requests and demands should be considered in the } \\
\text { determination of the advisor }\end{array}$ & 2 & 7,14 \\
\hline $\begin{array}{c}\text { At least 10 years working condition should not be } \\
\text { asked in consultants }\end{array}$ & 2 & 7,14 \\
\hline Voluntary basis should be considered in the advisors. & 2 & 7,14 \\
\hline Deep research should be done in finding an advisor & 2 & 7,14 \\
\hline The opportunities of schools should be considered & 1 & 3,57 \\
\hline $\begin{array}{c}\text { National Education Directorate should show the } \\
\text { necessary care and assistance }\end{array}$ & 1 & 3,57 \\
\hline Null & 1 & 3,57 \\
\hline Total & 28 & 100 \\
\hline
\end{tabular}

As it can be seen in Table 5, according to the answers given by the candidate teachers who participated in the study to the question "What are your views on the advisor teacher's determination and not being able to change him/her throughout the process?" are; $25 \%$ of them "Advisor can be changed", $25 \%$ of them "Advisor should not to change", $10,73 \%$ of them "Advisor's competence should be considered", 7,14\% of them "Requests and demands should be considered in the determination of the advisor", 7,14\% of them "At least 10 years working condition should not be asked in consultants", 7,14\% of them "Voluntary basis should be considered in the advisors.", 7,14 \% of them "Deep research should be done in finding an advisor", $3,57 \%$ of them "The opportunities of schools should be considered", 3,57\% of them "National Education Directorate should show the necessary care and assistance" and 3,57\% of them expressed no opinions about the question. Both positive and negative results have emerged in relation to the fact that the advisor teacher cannot be changed during the candidate teacher training 
process. According to $\mathrm{CT}-12$, different information should be obtained from different teachers by exchanging advisor teachers. According to CT - 6, that the advisor is not changed removes the teacher's compliance problem. It was determined that the qualifications and quality of the advisor teacher, voluntary basis, the opportunities of the schools and the preferences of the candidate teacher should be taken into consideration in the selection of the advisor teacher as $\mathrm{s} / \mathrm{he}$ is going to help the candidate teacher during the training.

Table 6. The frequency and percentage values of the answers to the question "What was the view of both the staff and the students at the school where you were in the candidacy training?"

\begin{tabular}{|c|c|c|}
\hline & f & $\%$ \\
\hline Administrators showed necessary respect & 7 & 19,5 \\
\hline Teachers showed the necessary respect & 6 & 16,6 \\
\hline $\begin{array}{c}\text { The students considered as candidates, trainees and } \\
\text { students }\end{array}$ & 6 & 16,6 \\
\hline Teacher exhibited distressed behavior & 4 & 11,2 \\
\hline Students showed the necessary respect & 3 & 8,4 \\
\hline I was not seen as a teacher & 3 & 8,4 \\
\hline Officials showed the necessary respect & 2 & 5,6 \\
\hline I was treated as a 2 ${ }^{\text {nd }}$ class teacher & 2 & 5,6 \\
\hline Executives show distressing behavior & 1 & 2,7 \\
\hline I was seen as an extra & 1 & 2,7 \\
\hline $\begin{array}{c}\text { Negative attitudes turned into positive ones after a } \\
\text { while }\end{array}$ & 1 & 2,7 \\
\hline Total & 36 & 100 \\
\hline
\end{tabular}

As it can be seen in Table 6, according to the answers given by the candidate teachers who participated in the study to the question "What was the view of both the staff and the students at the school where you were in the candidacy training?" are; $19,5 \%$ of them "Administrators showed necessary respect", $16,6 \%$ of them "Teachers showed the necessary respect", $16,6 \%$ of them "The students considered as candidates, trainees and students", $11,2 \%$ of them "Teacher exhibited distressed behavior", $8,4 \%$ of them "Students showed the necessary respect", $8,4 \%$ of them "I was not seen as a teacher", 5,6\% of them "Officials showed the necessary respect", $5,6 \%$ of them "I was treated as a $2^{\text {nd }}$ class teacher", $2,7 \%$ of them "Executives show distressing behavior", 2,7\% of them "I was seen as an extra", and 2,7\% of them "Negative attitudes turned into positive ones after a while." It was determined that the staff in the school in which the candidate training was given showed the necessary respect, there were two different situations in the behaviors of the teachers, and the students saw the candidate teachers as trainee teachers and students and as second class teachers. According to CT - 11, the period was completed before being exposed to any exclusions by both staff and teachers.

According to $\mathrm{CT}-10$, the candidate teachers were called by the students as trainee students, trainee teachers, and the candidate teachers were tried to make all chores as they were not seen as real teachers.
Table 7-a. The frequency and percentage values of the positive answers to the question "What are the practices you like and do not like in the process of training the candidate teachers?"

\begin{tabular}{|c|c|c|}
\hline Positive Thoughts & f & $\%$ \\
\hline Attending classes with experienced teachers & 2 & 28,6 \\
\hline Movies and books & 1 & 14,28 \\
\hline Being able to attend the course alone & 1 & 14,28 \\
\hline I've gained experience & 1 & 14,28 \\
\hline Not being able to attend the course & 1 & 14,28 \\
\hline If well-organized, it will be more efficient & 1 & 14,28 \\
\hline Total & 7 & 100 \\
\hline
\end{tabular}

As it can be seen in Table 7-a, according to the answers given by the candidate teachers who participated in the study to the question "What are the practices you like and do not like in the process of training the candidate teachers?" are; $28 \%$ of them "Attending classes with experienced teachers", $14,28 \%$ of them "Movies and books", $14,28 \%$ of them "Being able to attend the course alone", $14,28 \%$ of them "I've gained experience", $14,28 \%$ of them "Not being able to attend the course" and 14,28\% of them "If well-organized, it will be more efficient. In the candidate teacher training process, it has become clear that the candidate teachers enter the classroom with the experienced teachers to do observations, enter the classroom by themselves to apply theoretical knowledge they learned in the undergraduate education, and practice by assimilating what they learned from the advisor they observed, and they like the movies and the books which are recommended by the advisor teachers.

Table 7-b. The frequency and percentage values of the negative answers to the question "What are the practices you like and do not like in the process of training the candidate teacher?"

\begin{tabular}{|c|c|c|}
\hline Negative Thoughts & $\mathrm{f}$ & $\%$ \\
\hline I was considered as a trainee & 4 & 14,814 \\
\hline Administrative works were inefficient & 3 & 11,111 \\
\hline $\begin{array}{c}\text { The school managers sent candidate teachers to } \\
\text { their classes or idle class }\end{array}$ & 3 & 11,111 \\
\hline I didn't receive the respect I deserved as a teacher & 2 & 7,407 \\
\hline $\begin{array}{c}\text { We didn't attend the class alone and conducted the } \\
\text { any course }\end{array}$ & 2 & 7,407 \\
\hline No additional course fee & 2 & 7,407 \\
\hline The process was unnecessary & 2 & 7,407 \\
\hline My mistakes weren't corrected by the advisor & 1 & 3,704 \\
\hline Out-of-school activities were inefficient & 1 & 3,704 \\
\hline Lack of information about the process & 1 & 3,704 \\
\hline The process was unnecessarily long & 1 & 3,704 \\
\hline The fees which were paid for the exams were asked \\
to be paid back & 1 & 3,704 \\
\hline We were under the supervision of advisor & 1 & 3,704 \\
\hline Lack of controlling & 1 & 3,704 \\
\hline No watch fees & 1 & 3,704 \\
\hline Total & 1 & 3,704 \\
\hline We weren't considered as teachers & 27 & 100,00 \\
\hline & \\
\hline & 1 & \\
\hline
\end{tabular}


As it can be seen in Table 7-b, according to the answers given by the candidate teachers who participated in the study to the question "What are the practices you like and do not like in the process of training the candidate teacher?" are; $14,814 \%$ of them "I was considered as a trainee", $11,111 \%$ of them "Administrative works were inefficient", $11,111 \%$ of them "The school managers sent candidate teachers to their classes or idle class", $7,407 \%$ of them "I didn't receive the respect I deserved as a teacher", $7,407 \%$ of them "We didn't attend the class alone and conducted the any course", 7,407\% of them "No additional course fee", $7,407 \%$ of them "The process was unnecessary", 3,704 of them "My mistakes weren't corrected by the advisor", 3,704 of them "Out-of-school activities were inefficient", 3,704 of them "Lack of information about the process", 3,704 of them "The process was unnecessarily long", 3,704 of them "The fees which were paid for the exams were asked to be paid back", 3,704 of them "We were under the supervision of advisor", 3,704 of them "Lack of controlling", 3,704 of them "No watch fees" and 3,704 of them We weren't considered as teachers." In the process of the candidate teacher training, it has been revealed that the fact that the candidate teachers are seen as trainee students is the most important problem even though there are other applications the candidate teachers are satisfied with. According to CT - 10, the recognition of candidate teachers as trainees negatively affects perception as a teacher by students. In the same way, it was determined that even though they are sent to the idle courses and thought like a joker teacher, they cannot get their financial sense despite their entrance into the classroom, observing the advisor teacher and teaching the lecture under the supervision of the advisor are a waste of time within this application as it is the same as school practices course in the undergraduate curriculum, out-of-school activities are not efficient enough and there are serious malfunctions in the application because of lack of controlling. CT-11 stated that he could not get the respect he deserved as a teacher.

As it can be seen in Table 8, according to the answers given by the candidate teachers who participated in the study to the question "What are your views and suggestions in terms of better education given to candidate teachers within the program" are; $10,71 \%$ of them "Document load must be minimized", $10,71 \%$ of them "Candidate teachers should be activated with practice-oriented training", $10,71 \%$ of them "Process must be removed", $7,15 \%$ of them "Candidate process should be regulated and supervised", 7,15\% of them "Candidacy process should be shortened", $7,15 \%$ of them "Out-of-school activities should be improved", $7,15 \%$ of them "Plenty of time should be spent on administrative operations and plenty of practices should be done", $3,57 \%$ of them "Duties and responsibilities should be explained well to the advisor teachers", 3,57\% of them "Candidate process should be completed in the school they candidates are appointed",
$3,57 \%$ of them "This process should be finalized by adding it to the university final grade or extending the university education to 5 years", $3,57 \%$ of them "Candidate teacher should not be called as trainee", $3,57 \%$ of them "Summer seminar should not exist", $3,57 \%$ of them "Additional course fee should be paid", $3,57 \%$ of them "Advisors should be paid an additional fee", 3,57\% of them "Qualified advisor must be elected", 3,57\% of them "Candidate process can be completed in the district", $3,57 \%$ of them "With a nation-wide planning, they should act jointly" and 3,57\% of them" Support units must be created"

Table 8. The frequency and percentage values of the answer to the question "What are your views and suggestions in terms of better education given to candidate teachers within the program"

\begin{tabular}{|c|c|c|}
\hline Views and Recommendations about the Process & $\mathrm{f}$ & $\%$ \\
\hline Document load must be minimized & 3 & 10,71 \\
\hline $\begin{array}{l}\text { Candidate teachers should be activated with } \\
\text { practice-oriented training }\end{array}$ & 3 & 10,71 \\
\hline Process must be removed & 3 & 10,71 \\
\hline $\begin{array}{l}\text { Candidate process should be regulated and } \\
\text { supervised }\end{array}$ & 2 & 7,15 \\
\hline Candidacy process should be shortened & 2 & 7,15 \\
\hline Out-of-school activities should be improved & 2 & 7,15 \\
\hline $\begin{array}{l}\text { Plenty of time should be spent on administrative } \\
\text { operations and plenty of practices should be done }\end{array}$ & 2 & 7,15 \\
\hline $\begin{array}{l}\text { Duties and responsibilities should be explained } \\
\text { well to the advisor teachers }\end{array}$ & 1 & 3,57 \\
\hline $\begin{array}{c}\text { Candidate process should be completed in the } \\
\text { school they candidates are appointed }\end{array}$ & 1 & 3,57 \\
\hline $\begin{array}{l}\text { This process should be finalized by adding it to the } \\
\text { university final grade or extending the university } \\
\text { education to } 5 \text { years }\end{array}$ & 1 & 3,57 \\
\hline Candidate teacher should not be called as trainee & 1 & 3,57 \\
\hline Summer seminar should not exist & 1 & 3,57 \\
\hline Additional course fee should be paid & 1 & 3,57 \\
\hline Advisors should be paid an additional fee & 1 & 3,57 \\
\hline Qualified advisor must be elected & 1 & 3,57 \\
\hline Candidate process can be completed in the district & 1 & 3,57 \\
\hline $\begin{array}{l}\text { With a nation-wide planning, they should act } \\
\text { jointly }\end{array}$ & 1 & 3,57 \\
\hline Support units must be created & 1 & 3,57 \\
\hline Total & 28 & $\begin{array}{c}100,0 \\
0\end{array}$ \\
\hline
\end{tabular}

\section{Results and Recommendations}

As a result of the conducted study; with the training received during the candidate teacher training process, the candidate teachers mostly expressed positive opinions about the experience of the advisor and the teachers who gave the seminar, having information about the school work and operations, experience. Also known as "Turkey's candidate Teacher Training Model for Monitoring and Evaluation" report also has generally positive views about 
education teacher candidate nomination process and application. (SETA, 2017). Similar studies support our findings. (Gül, at all. 2017, Gökulu, 2017, Tünay, 2017; Alataş, 2017). At the same time, in similar studies, teachers from different working groups stated that candidacy education provides indirect and direct benefits. However, due to the fact that most of the time is filled with paperwork, they have expressed negative opinions about wasting time, not attending the class alone, being excluded by other teachers in the school, extending the process unnecessarily and not having summer vacation. Parallel to my failure to work in another study, prospective teachers expressed the negative aspects of the process such as uncertainty in the candidacy education, excessive paperwork, problems with the supervision, taking the summer vacation, very long and unnecessary seminars, and experiencing problems with other teachers (Gül, vd. 2017, Alataş, 2017).Candidate teachers in Pala's (2017) working group did not find the application of candidacy education generally effective and effective, and they were abstaining from the application. Candidate teachers have been hesitant to consider the effectiveness of other practices only in terms of their development, finding that the work done with school management is effective. However, in Pala's work, counselors think that the practice "has contributed to personal development, increased interest in the teaching profession, and that the profession has positively influenced motivation". In the study of Alataş 'in (2017), candidate teachers stated that they had problems in completing the form. Even though there are a positive and negative answers in equal proportion to the fact that the advisor teacher cannot be changed during the course, the classroom teachers stated that they benefited from the experience of the advisor teachers related to his/her guidance during the process, they learned about classroom management and fulfilled the duties and responsibilities of the advisor teachers. In the study of Alataş 'in (2017), candidate teachers think that they contribute to their professional development by fulfilling their duties and responsibilities of consultant teachers. Gul, Turkmen and Aksel (2017) also achieved parallel results. However, unlike our work in this study, participants often stated that the counseling task should be given to experienced and voluntary teachers. Likewise, in the study of Pala (2017), candidate teachers have reached the conclusion that the consultant teachers should be of better quality. In the study of Gökulu (2017), the candidate teachers in the study group, different from our study group, reached the conclusion that the advisor teachers did not provide sufficient support during the candidacy training process. Teachers who participated in the study indicated that the staff at the school where the candidacy training was held showed the necessary respect but that the students considered the candidate classroom teachers as trainee students and teachers and treated them accordingly. In another study parallel to my study, candidate teachers stated that they had a motivation problem due to the internship positions and approaches in the schools (Pala, 2017).

While it is the best part of the education to attend the courses with the advisor teachers according to the candidate classroom teachers in the study group during the candidate teacher training process, that the candidate teachers are considered as trainees, the ineffectiveness of the administrative work, that the candidate teachers are made to attend idle courses by the administrators are the dissatisfying sides of the process. In a similar study, prospective teachers considered the advantages of candidacy education for classroom management as a superior aspect of the process (Gül, et al., 2017).In terms of better education given to candidate teachers within the program, they pointed out that the most important thing is to reduce the burden of documents, to activate the candidate teachers with practical education, to shorten the candidacy education period, to improve the out of school activities, Similar results were obtained in other studies related to candidacy education process in the field of literature (Pala, 2017; Alataş, 2017).The following suggestions can be made from these results:

- Shortening the duration of the candidate teacher training program,

- Candidacy process should be completed in the appointed school,

- Voluntary basis and quality and adequacy of the advisor teacher should be taken into consideration in the selection of him/her,

- With a good management and organization, of the advisor teachers should be well informed about their duties and the responsibilities,

- The advisor teachers should fulfill their duties and responsibilities fully in the training of candidate teachers,

- Increasing the number of applications by shortening the observation week in the candidate teacher training process,

- More time should be spared for administrative works and more practices should be done,

- Improving the out-of-school activities,

- Reducing the number of the forms,

- Support units should be created,

- Motivational meetings with candidate teachers on a monthly basis in the presence of supervisor teachers should be organized

- Re-auditing the candidate teacher training program and correcting the problems in practice.

\section{REFERENCES}

[1] Akyüz, Y. (2014). Türk eğitim tarihi. Ankara: Pegem Akademi. 
[2] Akman, Y., Erden M. (2012). Eğitim psikolojisi (gelişim öğrenme - öğretme). Ankara: Arkadaş Yayınları.

[3] Alataş, H. (2017). Türkiye' de 2016 y1lında uygulanan "Aday Öğretmen Yetiștirme Programı" uygulamasının değerlendirilmesi, (Yüksek Lisans Tezi). Yüzüncü Y1l Üniversitesi, Van.

[4] Alkan, S. (2012). AB ülkelerinde öğretmen yetiştirme programlarıla Türkiye'deki öğretmen yetiştirme programının karşılaştırılması ve Türkiye için bir model önerisi. (Yayımlanmamış Yüksek Lisans Tezi). Mustafa Kemal Üniversitesi Sosyal Bilimler Enstitüsü, Hatay.

[5] Altın, H. (2009). II. Abdülhamit ve II. Meşrutiyet devirlerinde öğretmen yetiştirme meselesi, (Yayımlanmamıs Doktora Tezi). Ankara Üniversitesi Sosyal Bilimler Enstitüsü, Ankara.

[6] Başaran, M. (1999). Devrimci eğitim-köy enstitüleri. İstanbul: Papirüs Yayınevi Anı Dizisi.

[7] Büyüköztürk, Ş. (2015). Bilimsel araştırma yöntemleri. Ankara: Pegem Akademi.

[8] Christensen, L. B., Johnson, B., and Turner, L. A. (2015). Araştırma yöntemleri: Desen ve analiz. Ankara: Anı Yay.

[9] Çalık, T. (2006). Eğitimle ilgili bazı temel kavramlar. Leyla Küçükahmet (Ed.), Eğitim bilimine giriş. Ankara: Nobel Yayınları.

[10] Çelikkaya, H. (2010). Eğitim bilimlerine giriş eğitimcilik ve öğretmenlik. Ankara: Nobel Yayınları.

[11] Gök, H.V. (2011). Atatürk ve İnönü dönemi eğitim politikaları. (Yayımlanmamış Yüksek Lisans Tezi). Ahi Evran Üniversitesi, Kırşehir.

[12] Gökulu, A. (2017). Aday öğretmenlerin Türkiye'deki aday öğretmenlik eğitim süreci ile ilgili görüşleri. Journal of Social Sciences and Education Research, 3(1), 111-123.

[13] Gül, İ., Türkmen, F., Aksel, N., (2017). Aday Öğretmen Görüşlerine Göre Aday Öğretmen Yetiştirme Sürecinin Değerlendirilmesi, Hitit Üniversitesi Sosyal Bilimler Dergisi,
$10(1)$

[14] Karahan, N. (2008). Öğretmen yetiștirme düzeni ve Türkiye örneği. (Yayımlanmamış Yüksek Lisans Tezi). Beykent Üniversitesi, İstanbul.

[15] Kodaman, B. (1999). II. Abdulhamid devri eğitim sistemi. Ankara: T.T.K. Yayını.

[16] MEB, (2016). Aday öğretmen yetiștirme sürecine ilișkin yönerge. Milli Eğitim Bakanlığı Tebliğler Dergisi.

[17] Pala, A. (2017). MEB ilkokul ve ortaokul eğitim kurumlarına atanan aday öğretmenlere uygulanan mentorluk süreci, (Yüksek Lisans Tezi). Gaziantep Üniversitesi, Gaziantep.

[18] SETA, (2017). Türkiye' de Aday Öğretmen Yetiștirme Modeli İzleme ve Değerlendirme Raporu, (Hazırlayanlar; İbrahim Emre İlyas, İpek Coşkun, Dilruba Toklukcu), Siyaset Ekonomi Toplum Araştırmaları Vakfi.

[19] Sünbül, A.M. (1996). Öğretmen niteliği ve öğretimdek rolleri, Eğitim Yönelimi, 2(1), 597-607.

[20] Şeker, K. (2000). İnönü dönemi kültür hayatı (1938 - 1950), (Doktora Tezi). Süleyman Demirel Üniversitesi, Isparta.

[21] Şimşek, H. (2014). Osmanlı döneminde kısa süreli öğretmen yetiştirme uygulamaları (darulameliyat ve taşrada öğretmen yetiștirme). YYÜ Eğitim Fakültesi Dergisi (YYU Journal Of Education Faculty), 11(1), 77-95.

[22] Şişman, M. (2006). Eğitim bilimine giriş. Ankara: Pegem A.

[23] Toprak, G.N. (2008). Cumhuriyetin ilk döneminde Türk eğitim sistemi ve köy enstitüleri. (Yayımlanmamış Yüksek Lisans Tezi). Kocatepe Üniversitesi, Afyonkarahisar.

[24] Tünay, T. (2017). MEB aday öğretmen yetiștirme süreci uygulamasının öğretmen bakış açısıyla değerlendirilmesi. Yüksek Lisans Tezi. Karabük Üniversitesi, Karabük.

[25] Yüksel, M. (2014). Bilgi çağında değișen eğitim paradigmaları çerçevesinde öğretmen istihdamı: Türkiye örneği (Yayımlanmamış Doktora Tezi). Süleyman Demirel Üniversitesi Sosyal Bilimler Enstitüsü, Isparta.

\footnotetext{
${ }^{\mathrm{i}}$ This study was presented in II. International Social Sciences Conference (12th-14th October 2016-Ağrı)
} 